\title{
Investigation of the Metaphorical Perceptions of the Gifted Students Related to the Concept of Science and Art Center (SAC)
}

\author{
Ismail Satmaz ${ }^{1}$, Hasan Said Tortop ${ }^{2} \&$ Elmaziye Temiz ${ }^{3}$ \\ ${ }^{1}$ Math teacher, Turgut Reis Secondary School, Çanakkale, Turkey \\ ${ }^{2}$ Assoc.Prof., Istanbul Aydın University, Faculty of Education, Special Education Department, Istanbul, Turkey \\ ${ }^{3}$ Dr. Çanakkale 18 March University, Faculty of Education, Çanakkale, Turkey, elmaziyetemiz@ gmail.com
}

Received: April 4, $2018 \quad$ Accepted: April 28, $2018 \quad$ Online Published: July 17, 2018

doi:10.5539/hes.v8n3p34 URL: https://doi.org/10.5539/hes.v8n3p34

\begin{abstract}
This study aims to reveal the metaphorical perceptions related to the concept of Science and Art Center (SAC,) which is a state institution where the gifted students in Turkey receive support for their education. For this purpose, gifted students were asked to produce metaphors about SAC concepts. The participants of the research are 59 students attending Çanakkale SAC in Çanakkale city, Turkey. However, 52 students areincluded in the study. The research is based on the phenomenological approach of qualitative research methods. The data of the study were collected by metaphor questionnaire consisting of two parts. The collected data were analyzed by content analysis method. In[HST1] the direction of the data obtained from the research, the perceptions of SAC of the gifted students were revealed. The perceptions of gifted students in the study were examined in terms of changes in gender and the education program they were enrolled. It has been found that gifted students have perceptions related to SAC in seven categories: safe and relaxing environment, source and conveyor of information, developer and guiding, entertaining learning environment, beneficial learning environment, astonishing learning environment and boring learning environment. Two different data coding systems were used to reveal 7 different categories, The result was checked in accordance with Miles and Huberman reliability coefficent and the result was $91 \%$.
\end{abstract}

Keywords: science and art center (SAC), metaphor, gifted students

\section{Introduction}

The individual, the society and the state are related elements in terms of education. As seen in the 21 st century, this relationship is increasingly important. The higher the level of education, knowledge and equipment of individuals the stronger the societies are. Today, the economy of a company founded by an indiviual may be more powerful than the economy of many states. Undoubtedly, the individuals who set up these companies are individuals with superior characteristics (Evin Gencel and Satmaz, 2016).The Turkish Ministery of National Education (2015) defines a gifted student as a student whose intelligence, creativity, the abilty to produce work of art or leadership are at a higher level, or performs better in specific academic departments compared to his or her peers. Gifted or talented individuals have the potential to create important works for the history of mankind with a well-structured education (Tortop, 2015; Keskin et al., 2013). A gifted child is a child who performs better in at least one skill or intellectual talent than his/her peers or possesses an intellectual latent power and has average qualities in different areas (Akkanat, 2004). there is no doubt that special programs should be implemented to children with these characteristics. These individuals, who are called in the literature as talented, gifted, brilliant students or specially talented students, should be monitorized by the society and special programs should be designed for their development. İdentified by specialists, gifted children, who perform at a higher level than their peers in terms of mental ability, are the groups that need enriched, accelerated, differentiated, and individualized programs of their own interests and abilities rather than traditional education programs (Kaya, 2013; Tortop, 2015).

By taking into account theconcepts equality and justice in education, special education needs of gifted students should be addressed (Ehly et al., 1985). Institutions that will meet the educational needs of these students should be founded quickly by the state or private institutions. Science and Art Centers, first established in Ankara in 1994 and reaching to 105 centers in early 2017, serve for the gifted and talented students. Gifted students, in parallel with their formal education, study the field in which they have superior talent together with their talented 
peers from other schools and field teachers in SACs. while the integration of these students into the society is provided in their own schools, SACs provide them with the opportunity to recognize their talents and develop their capabilities (Satmaz and Evin Gencel, 2015).

The education that gifted students receive at these centers is of great significance. Undoubtedly, the education they receive here, ensures the development of their special capabilities Thanks to the differentiated and enriched education they experience, they acquire the skills of problem solving in daily life as well as acquiring high-level cognitive skills such as analysis, synthesis and evaluation as well. Apart from concrete thinking skills, studies about abstract thinking skills are also expected. These children, who perceive abstract concepts better than their peers, may be idealsubjects for the study since they can understand and use content that has various meaning levels such as complex metaphors with similar meanings, similar paradoxes in the content of subjects (Meyen \& Skrtic, 1988). Gifted children are the bright children of science that will lead the next generation. The metaphors produced by these children, who will be the managers of the future, are extremely of importance.

"metaphor" originates from the Greek word Metaphora, means transfer or carry over. Metaphor in the Turkish Language Association (TLA, 2016) dictionary is defined as; "A word that is used in a sense other than the meaning of an interest or a result of analogy; Using a word or concept in a way other than its accepted meaning".

In this study, it was aimed to reveal the metaphorical perceptions of the gifted students related to the Science and Art Center (SAC), which is one of the leading institutions where the gifted students in Turkey receive support for their education. This will then hopefully lead to studies about the efficiency of the education in these institutions. The problem of the study is;

$>$ What is the metaphorical perception of gifted students related to Science and Art Center?

$>$ How can the gifted students' metaphorical perceptions of SAC be categorized?

$>$ How are the gifted students' metaphorical perceptions of SAC changed according to gender and education programs they were enrolled?

\section{Method}

\subsection{Research Model}

A phenomenographic approach was chosen from the qualitative research methods. This kind of aproach tries to reveal the experiences, and the perceptions of the individuals related to a case. Sources in phenomology studies are the individualsor groups that reflect the phenomenon in the studied case. Through data analysis in phenomenology studies, we can reveal experiences and meanings. The results emerge with a descriptive narrative and direct quotations are given. Whereas the phenomenology studies do not provide clear, generalizable, and appropriate results for the nature of the qualitative research, they provide meaningful data to be able to understand the phenomenon we have (Yıldırım \& Şimşek, 2012; Miles \& Huberman, 1994). The researcher tried to reveal the metaphorical perceptions of SAC concept of the gifted students. During the analysis, the qualitative difference categories weretried to be determined first. Then, it was revealed how the participants perceive the events and the concepts, and finally the researcher started to present the categories by comparing the similarities and differences among the participants (Baş and Akturan, 2008).Phenomenological research model was used to investigate the metophorical perceptions profoundly.

\subsection{Research Group/Participants}

To determine the research group, criteria sampling method of the purposive sampling methods was used. Individuals to be determined as participant in the criterion sample are covered into sampling by some certain criterias (Yıldırım and Şimşek, 2012; Miles \& Huberman, 1994).

Table 1. Demographic characteristics of participants

\begin{tabular}{lll}
\hline Variable & Demographic Characteristics & (f) \\
\hline Gender & Female & 28 \\
& Male & 24 \\
Enrolled Education Programs & Support Training Program & 17 \\
& Individual Capabilities Recognition Program & 17 \\
& Special Capabilities Development Program & 18 \\
\hline Total & & 52 \\
\hline
\end{tabular}

The study group of the research consisted of 59 students enrolled in Çanakkale SAC educational institution in Canakkale province in 2015-2016 academic year in Turkey. Of the participants from this educational institution, 
52 were included in the research consisting of 28 female and 24 male students. Seventeen of the participants were continuing their education in Support Training Program, another seventeen were in Individual Capabilities Recognition program and 18 were in Special Capabilities Development program.

Support Training Program is a program which was designed for the students who complete the integration program at SACs for a duration of one year. They can work individually or as a group of students. These students are expected to participatesix hours per week in elementary school level and eight hours per week at the secondary school level. Students are aimed to acquire scientific research techniques, group working techniques, communication skills, problem solving techniques and learning skills in this education program. In the Support Training Program, students are expected to be divided into groups and gain creative thinking, critical thinking, decision-making skills and effective use of resources. SACs are institutions where interdisciplinary approach is implemented. The subjects of this interdisciplinary aproach are science, mathematics, Turkish, social sciences, foreign language, information technology, technology and design, visual arts in educational programs. Theme/workshop based activities are applied to enrichi, differentiate and accelerate during the support training program implementation process. Feedbacks based on measurement tools are taken during and after the support training program (MNE SAC Directive, 2015).

Individual Capabilities Recognition Program: After completing the support program students, then; are seperated in to groups to attend Capabilities Recognition Program. It is applied for 2 years as a total of 8 lessons, 4 hours a week. This education program is prepared with the modular structure and student-centered education understanding. The project production studies are continued considering the interdisciplinary relations in the period of distinguishing individual capabilities and the projects are prepared more comprehensively than the support training program.

\subsection{Data Collection}

The researcher collected the data during 2015-2016 academic year. Metaphor questionnaire form and data collection procedure took 5 business days. The collection of the data from the semi-structured interview form lasted in 3 business days.

The reason for using the metaphor questionnaire is that the data can be obtained in a shorter time and more people can be reached. The questionnaire form consisted of two parts.

First part included demographic information (gender and enrolled program);

Second part involved questions such as "SAC is like ....., because ....." to investigate the students' metaphorical perceptions of SAC concept.

Questions for collecting demographics and determining perceptions of students in data collection were created by reviewing the literature. The prepared metaphor form was presented to the expert view. After the literature review and expert view, the metaphor form was first applied to 13 students including 7 girls and 6 boys from a different school. Students were asked to produce 3 metaphors for the SAC concept. Upon request from the students, a statement "they can produce at least 1 maximum of 3 metaphors" was added. The main application of the questionnaire incorporated a total of 52 students, 28 female and 24 male students. Seventeen of these students were enrolled in Support training Program, another seventeen in Individual Capabilities Recognition Program and 18 in Special Capabilities Development Program. Student names were replaced by participant code. In addition, expert view was taken after the corrections weremade in the preliminary application. By finalizing the metaphor questionnaire form considering expert opinions and practices made, a valid and reliable data collection tool was put forth which can take the opinions of the students related to the SAC concept.

\subsection{Data Analysis}

The data collected by metaphor questionnaire forms were analyzed by content analysis. To be able to reach the concepts and correlations that can explain the collected data in content analysis is the main purpose of the study. The process for this purpose is to bring the similar data together within the framework of certain concepts and themes and to interpret them by organizing in a way that the reader can understand (Ylldırım \& Şimşek, 2012).

Analysis and interpretation of data obtained from the study was performed in five stages (Saban, 2009); naming/labeling stage, sorting (clarification and elimination) stage, sample metaphor compilation and categorization stage, validation and reliability stage, and transferring the data to the computer stage.

Naming/labeling Stage: At this stage, all valid and invalid metaphors obtained in the research were listed. In total, 102 metaphors related to SAC concept were produced.

Sorting (Clarification And Elimination) Stage: Among the listed metaphors and questionnaires the ones seen as 
invalid because of justification have been removed from the study. In this context, 8 of the 102 metaphors that the students produced related to the concept of SAC were found out to be invalid and removed from the study. Invalid metaphors were as followings; Very bad, the place I go every day, the cat, the butterfly, difficult, the good, very good and I don't know. As a result, the study was continued with 94 metaphors of SAC concept.

Sample Metaphor Compilation And Categorization Stage: At this stage, the produced metaphors were examined separately by each researcher in terms of their common characteristics regarding the concept of SAC. Thus, each researcher first collected the metaphors under their own conceptual categories. Two data coding systems were used to analyse the data. 7 different categories were defined with a 91\% Mills and Huberman reliablity coefficent.

Validation and Reliability Stage: All researchers analyzed and interpreted the data from the questionnaire in terms of validity and reliability of the research. The gifted students' metaphorical perceptions of the SAC concept were analyzed a total of 5 times.

According to Ghiglione (1978), the reliability of the metaphor analysis is largely dependent on the coding process (as cited in Bilgin, 2000). Reliability in metaphor analysis is concerned with the reliability of encoders and coding categories. The reliability of encoders can be achieved in two ways. Expert opinion on the suitability of groupings can be taken in order to ensure the reliability of the measurements. In addition, the researcher re-encoded the same texts at different times to obtain data on the reliability of grouping.

In the study, Miles and Huberman's formula (1994) which the researcher proposed for reliability was used; R $($ Reliability $)=$ Agreement $/$ Agreement + Disagreement. The reliability coefficient was calculated as $91 \%$. Over $70 \%$ reliability is considered sufficient for reliability (as cited in Küçükyılmaz ve Duban, 2006).

Transferring The Data To The Computer Stage: At this stage, the accepted and finalized metaphorsand the conceptual themes composed of these metaphors were transferred to a computer. All tables that represent sub-problems have been converted into tables in Microsoft Office Excel 2007. After this process, the number of participants (f) and percentages (\%) were calculated according to the gender and the education programs they were enrolled by considering the categories. After the interview with the students, the data was transferred to a computer using Microsoft Word program.

\section{Results}

The findings of the research are explained in four main headings in accordance with the questions in the metaphor questionnaire.

\subsection{Theme 1. Gifted Students' Metaphorical Perceptions of the "SAC" Concept}

The answers given by the students are grouped and all the metaphors and the metaphors related to sub problems are given as tables. The metaphors of gifted students regarding the concept of "SAC" are shown in Table 2. 
Table 2. All metaphors the participants produced regarding the SAC concept

\begin{tabular}{lllllllll}
\hline No & Metaphor & f & No & Metaphor & f & No & Metaphor & f \\
\hline 1 & School & 8 & 23 & climber & 1 & 45 & happiness & 1 \\
2 & book & 5 & 24 & notebook & 1 & 46 & music & 1 \\
3 & entertainment & 4 & 25 & experiment & 1 & 47 & music box & 1 \\
4 & home & 4 & 26 & lesson & 1 & 48 & game & 1 \\
5 & family & 3 & 27 & fellow & 1 & 49 & Learning place & 1 \\
6 & mom & 3 & 28 & Fun fair & 1 & 50 & freedom & 1 \\
7 & friend & 2 & 29 & Build a house & 1 & 51 & Number Pi & 1 \\
8 & farmer & 2 & 30 & factory & 1 & 52 & project & 1 \\
9 & world & 2 & 31 & film & 1 & 53 & compass & 1 \\
10 & life & 2 & 32 & future & 1 & 54 & guide & 1 \\
11 & course & 2 & 33 & sky & 1 & 55 & love & 1 \\
12 & music & 2 & 34 & glasses & 1 & 56 & boring place & 1 \\
13 & Play house & 2 & 35 & sun & 1 & 57 & Magic box & 1 \\
14 & teacher & 2 & 36 & dairy & 1 & 58 & Family tree & 1 \\
15 & canvas & 2 & 37 & light & 1 & 59 & sport & 1 \\
16 & tree & 1 & 38 & glint & 1 & 60 & song & 1 \\
17 & garden & 1 & 39 & dude & 1 & 61 & yard & 1 \\
18 & brain & 1 & 40 & moneybox & 1 & 62 & technology & 1 \\
19 & Info house & 1 & 41 & Amusement Park & 1 & 63 & master & 1 \\
20 & computer & 1 & 42 & maths & 1 & 64 & leaf & 1 \\
21 & heaven & 1 & 43 & ladder & 1 & 65 & pillow & 1 \\
22 & flower & 1 & 44 & candle & 1 & 66 & star & 1 \\
& & & & & 67 & nest & 1 \\
\hline Total & & & & & & 94 \\
\hline
\end{tabular}

"School" metaphor stands out as the most frequent one. The metaphors produced by Participant 4, Participant 5 and Participant 21 are as follows.

"SAC is like a school. Because it supports our education."

"SAC is like a school. Because it gives us information."

"SAC is like a school. Because we receive beneficial lessons there."

"School" metaphor was followed by "book" metaphor(f5); " entertainment"(f4) and "home" (f4)metaphors. The metaphors produced by Participant 51, Participant 46 and Participant 6 are as follows.

"SAC is like a book. Because it leads us."

"SAC is like entertainment. Because enjoy it."

"SAC is like home. Because I feel comfortable."

Table 3 shows conceptual categories of students' perception of SAC concept.

Table 3. Metaphors and categories of SAC concept of gifted students

\begin{tabular}{lll}
\hline Categories & $\begin{array}{l}\text { Number of } \\
\text { Metaphors }\end{array}$ & $\begin{array}{l}\text { Number of } \\
\text { Different Metaphors }\end{array}$ \\
\hline SAC as safe and relaxing environment & 24 & 16 \\
SAC as the source and conveyor of the information & 23 & 13 \\
SAC as developmental and guiding environment & 20 & 19 \\
SAC as Entertaining learning environment & 16 & 12 \\
SAC as beneficial learning environment & 5 & 5 \\
SAC as surprising learning environment & 5 & 5 \\
SAC as boring learning environment & 1 & 1 \\
Total & 94 & 71 \\
\hline
\end{tabular}

Seven different themes were created by the researcher; SAC as a safe and relaxing environment with 24 metaphors (f:16), SAC as the source and conveyor of information with 23 metaphors (f:13), SAC as a 
developmental and guiding environment with 20 metaphors (f:19), SAC as an Entertaining learning environment with 16 metaphors (f:17), SAC as a beneficial learning environment with 5 metaphors (f:5), SAC as a surprising learning environment with 5 metaphors (f:5), SAC as a boring learning environment with 1 metaphor (f:1).

It was determined that 24 participants produced metaphors regarding a safe and relaxing environment of SAC.

Table 4. SAC as safe and relaxing environment

\begin{tabular}{llllll}
\hline No & Metaphor & $\mathrm{f}$ & No & Metaphor & $\mathrm{f}$ \\
\hline 1 & family & 3 & 9 & world & 1 \\
2 & mom & 3 & 10 & music & 1 \\
3 & home & 3 & 11 & freedom & 1 \\
4 & friend & 2 & 12 & love & 1 \\
5 & canvas & 2 & 13 & Family tree & 1 \\
6 & tree & 1 & 14 & song & 1 \\
7 & heaven & 1 & 15 & pillow & 1 \\
8 & flower & 1 & 16 & nest & 1 \\
\hline Total & & & & & $\mathbf{2 4}$ \\
\hline
\end{tabular}

16 metaphors were produced regarding SAC as a safe and relaxing environment. Frequency of generated metaphors is between 1-3. The most repeated metaphors are the metaphor of "family", "mom", and "home"(f:3). The metaphors produced by participant 11, participant 7 and participant 1 are.

"SAC is like my family. Because I find the same warm atmosphere here."

"SAC is like my mother. Because she supports me in every way. "

"SAC is like my home. Because I'm comfortable here. "

These metaphores are followed by "friend" and "canvas"(f:2). Metaphors produced by participant 24 and 52 are.

"SAC is like a friend. Because I'm having a nice time there "

"SAC is like a canvas. Because there are beauties on it. "

It was determined that 16 participants produced metaphors relatedSAC. as an entertaining environment.

Table 5. SAC as entertaining learning environment

\begin{tabular}{llllll}
\hline No & Metaphor & f & No & Metaphor & f \\
\hline 1 & Entertainment house & 4 & 7 & life & 1 \\
2 & Play house & 2 & 8 & dude & 1 \\
3 & lesson & 1 & 9 & Amusement park & 1 \\
4 & fellow & 1 & 10 & happiness & 1 \\
5 & Fun fair & 1 & 11 & Music box & 1 \\
6 & house & 1 & 12 & Play house & 1 \\
\hline Toplam & & & & & $\mathbf{1 6}$ \\
\hline
\end{tabular}

A total of 12 metaphors were produced describing SAC as an entertaining environment. Frequency of generated metaphors is between 1 and 4 . The most frequently repeated metaphor is the "entertainment house" (f:4). The metaphors produced by Participant 3 and Participant 44 are as follows.

"SAC is like an entertainment house. Because we have a nice time here too "

"SAC is like an entertainment house. Because we learn by entertaining. "

These metaphors are followed by "play house"(f:2). The metaphor produced by participant 47 is

"SAC is like a play house. Because we learn new information without being bored here."

It was determined that 20 participants produced metaphors regarding $\mathrm{SAC}^{\prime}$ as a developmental and guiding environment. 
Table 6. SAC as developmental and guiding

\begin{tabular}{llllll}
\hline No & Metaphor & f & No & Metaphor & f \\
\hline 1 & farmer & 2 & 10 & book & 1 \\
2 & brain & 1 & 11 & ladder & 1 \\
3 & climber & 1 & 12 & candle & 1 \\
4 & experiment & 1 & 13 & teacher & 1 \\
5 & Build a house & 1 & 14 & compass & 1 \\
6 & future & 1 & 15 & guide & 1 \\
7 & glasses & 1 & 16 & field & 1 \\
8 & dairy & 1 & 17 & technology & 1 \\
9 & light & 1 & 18 & master & 1 \\
& & & 19 & leaf & 1 \\
\hline Total & & & & $\mathbf{2 0}$ \\
\hline
\end{tabular}

A total of 19 different metaphors were produced comparing SACs as a developmental and guiding environment. Frequency of generated metaphors is between 1 and 2. The most repeated metaphor is the "farmer"(f:2). The metaphor produced by participant 25 is as following.

"SAC is like a farmer. Because there is a production here and the children are flowers. "

This metaphor is followed by the metaphors "brain", "climber", "experiment"(f:1). The metaphors produced by Participant 1, Participant 18 and Participant 26 are as follows.

"SAC is like glasses. Because they allow us to look at life from different fields. "

"SAC is like a teacher. Because it shows us the right way and makes us succeed. "

"SAC is like a compass. Because they show us the right way and let us focus on the goal. "

It was determined that 24 participants produced metaphors regarding SACs as the source of information and its conveyor environment.

Table 7. SAC as the source and conveyor of the information

\begin{tabular}{llllll}
\hline No & Metaphor & $\mathbf{f}$ & No & Metaphor & f \\
\hline 1 & school & 7 & $\mathbf{7}$ & notebook & 1 \\
2 & book & 4 & $\mathbf{8}$ & sky & 1 \\
3 & course & 2 & $\mathbf{9}$ & sun & 1 \\
4 & garden & 1 & $\mathbf{1 0}$ & Maths & 1 \\
5 & Info house & 1 & $\mathbf{1 1}$ & learning yeri & 1 \\
6 & computer & 1 & $\mathbf{1 2}$ & teacher & 1 \\
& & & $\mathbf{1 3}$ & star & 1 \\
\hline Total & & & & & $\mathbf{2 3}$ \\
\hline
\end{tabular}

A total of 15 different metaphors were produced regarding SACs as the source and conveyor of information environment. Frequency of generated metaphors is between 1 and 7. The most repeated metaphor is the "school" metaphor (f:7). The metaphor produced by Participant 5 and Participant 25 is as following.

"SAC is like a school. Because here we are informed. "

This metaphor is followed by the "book"(f:4). The frequency of all other metaphors is 1 . The metaphors produced by Participant 17, Participant 31 and Participant 34 are as follows.

"SAC is like a book. Because it contains a lot of information. "

"SAC is like the sun. Because it enlightens us."

"SAC is like a computer. Because it contains infinite information. "

It was determined that 5 participants produced metaphors related to SACs as the beneficial learning environment. 
Table 8. SAC as beneficial learning environment

\begin{tabular}{lll}
\hline No & Metaphor & f \\
\hline 1 & factory & 1 \\
2 & life & 1 \\
3 & school & 1 \\
4 & project & 1 \\
5 & sport & 1 \\
Total & & 5 \\
\hline
\end{tabular}

A total of 5 different metaphors were produced for SAC's beneficial learning environment. All generated metaphors are generated once. The metaphors produced by Participant 4 and Participant 19 are as follows.

"SAC is like sports. Because it benefits us."

"SAC is like a factory. Because a lot of projects are produced here. "

It was determined that 5 of the participants presented metaphors related to SACs as a surprising learning environment.

Table 9. SAC as surprising learning environment

\begin{tabular}{lll}
\hline No & Metaphor & f \\
\hline 1 & world & 1 \\
2 & film & 1 \\
3 & music & 1 \\
4 & pi & 1 \\
\hline 5 & Magic box & 1 \\
\hline Total & & 5 \\
\hline
\end{tabular}

A total of 5 different metaphors were produced for SAC's surprising learning environment. All generated metaphors are generated once. The metaphors produced by Participant 2, Participant 9 and Participant 37 are as follows.

"SAC is like a movie. Because you do not know how it starts and how it ends. "

"SAC is like a magic box. Because you do not know what will come out of it. "

"SAC is like number pi. Because it surprises us from every aspects of it. "

It was determined that 5 participants produced metaphors related to the SACs as a surprising learning environment.

Table 10. SAC as boring learning environment

\begin{tabular}{lll}
\hline No & Metaphor & f \\
\hline 1 & Boring place & 1 \\
\hline Total & & 1 \\
\hline
\end{tabular}

A total of 1 metaphor related to the SAC as the boring learning environment was produced. The metaphor that Participant 23 produced is as following.

"SAC is like a boring place. Because time is not passing by and it makes me unhappy. "

\subsection{Frequency of Metaphors Related to SAC by Gender}

Table 11 shows the conceptual categories of the metaphores genarated by gifted students "SAC" in terms of gender variable. 
Table 11. Frequency of metaphors related to SAC concept by gender

\begin{tabular}{|c|c|c|c|}
\hline Conceptual Category & Female $(\mathrm{N}=28)$ & Male $(\mathrm{N}=24)$ & $\mathrm{f}$ \\
\hline $\begin{array}{l}\text { 1. SAC as Safe and } \\
\text { Relaxing Environment }\end{array}$ & $\begin{array}{l}\text { mom (f:3), family (f:2), tree (f:1), heaven } \\
\text { (f:1),flower (f:1), world (f:1), home (f:1), love } \\
\text { (f:1), family tree (f:1), song (f:1), freedom (f:1), } \\
\text { pillow (f:1), nest (f:1) } \\
\text { Metaphor:13, f:16 }\end{array}$ & $\begin{array}{l}\text { home (f:2), canvas (f:2), family (f:1), mom (f:1), } \\
\text { friend (f:1), music (f:1) } \\
\text { Metaphor: } 6, \mathrm{f}: 8\end{array}$ & 24 \\
\hline $\begin{array}{l}\text { 2. SAC as Entertaining } \\
\text { Learning Environment }\end{array}$ & $\begin{array}{l}\text { entertainment (f:3), play house (f:2), lesson (f:1), } \\
\text { fellow (f:1), fun fair (f:1), house (f:1), } \\
\text { life (f:1), hapiness (f:1), music box (f:1), game } \\
\text { (f:1) Metaphor:10, f:13 }\end{array}$ & $\begin{array}{l}\text { entertainment (f:1), dude (f:1), amusement park } \\
(\mathrm{f}: 1) \\
\text { Metaphor: } 3 \text {, f:3 }\end{array}$ & 16 \\
\hline $\begin{array}{l}\text { 3. SAC as Developmental } \\
\text { and Guiding Learning } \\
\text { Environment }\end{array}$ & $\begin{array}{l}\text { experiment (f:1), glasses (f:1), light (f:1), glint } \\
\text { (f:1), ladder (f: } 1) \text {, candle (f:1), guide (f:1), } \\
\text { technology (f:1), } \\
\text { Metafor:8, f:8 }\end{array}$ & $\begin{array}{l}\text { farmer (f:2), brain (f:1), climber (f:1), build a } \\
\text { house(f:1), future (f:1), book (f:1),teacher (f:1), } \\
\text { compass (f:1), field (f:1), master (f:1), leaf (f:1) } \\
\text { Metaphor: } 11, f: 12\end{array}$ & 20 \\
\hline $\begin{array}{l}\text { 4. SAC as Source and } \\
\text { Conveyor of Information }\end{array}$ & $\begin{array}{l}\text { book (f:2), garden (f:1), computer (f:1), } \\
\text { info house (f:1), sky (f:1), sun (f: } 1) \text {, } \\
\text { course (f:1), maths (f:1), school (f:1), } \\
\text { learning place (f: } 1) \text {, teacher (f:1), star (f:1) } \\
\text { Metaphor: } 12, f: 12\end{array}$ & $\begin{array}{l}\text { school (f:6), book (f:2), notebook (f:1), moneybox } \\
(f: 1) \text {, course (f:1) } \\
\text { Metaphor:5, f:11 }\end{array}$ & 23 \\
\hline $\begin{array}{l}\text { 5. SAC as Beneficial } \\
\text { Learning Environment }\end{array}$ & $\begin{array}{l}\text { factory (f: } 1), \text { life (f: } 1) \\
\text { Metaphor: } 2, \mathrm{f}: 2\end{array}$ & $\begin{array}{l}\text { school (f: } 1) \text {, project (f:1), sport (f:1) } \\
\text { Metaphor:3, f:3 }\end{array}$ & 5 \\
\hline $\begin{array}{l}\text { 6. SAC as Surprising } \\
\text { Learning Environment }\end{array}$ & $\begin{array}{l}\text { world (f:1), music (f:1), number pi (f:1) } \\
\text { Metaphor: } 3, \mathrm{f}: 3\end{array}$ & $\begin{array}{l}\text { film (f: } 1) \text {, magic box (f:1) } \\
\text { Metaphor: } 2, \mathrm{f}: 2\end{array}$ & 5 \\
\hline $\begin{array}{l}\text { 7. SAC as Boring } \\
\text { Learning Environment }\end{array}$ & Metaphor: 0, f:0 & $\begin{array}{l}\text { Boring place (f:1) } \\
\text { Metaphor: } 1, \mathrm{f}: 1\end{array}$ & 1 \\
\hline Conceptual Category & Female $(\mathrm{N}=28)$ & Male $(\mathrm{N}=24)$ & $\mathrm{f}$ \\
\hline
\end{tabular}

As shown the table 11, female students produced 13 different metaphors (f: 16) and male students produced 6 different metaphors (f: 8) about SAC as a safe and relaxing environment The frequency of generated metaphors is between 1 and 3 in female students and between 1 and 2 in male students. The metaphor of "mom" is the most frequently repeated metaphor among the female students, and "home" and "canvas" metaphors are the most frequently repeated metaphors among male students. The metaphors produced by participant 30 and participant 8 are as follows.

"SAC is like my mother. Because it always protects me. "

"SAC is like home. Because I'm resting there. "

In the category "SAC as an entertaining learning environment", female students produced one metaphor (f: 10) and male students produced 3 metaphors (f: 3 ). The frequency of generated metaphors is between 1 and 3 in female students and 1 in male students. The most frequently repeated metaphor by girls is the "entertainment" metaphor, and by boys all metaphors ("entertainment", "dude" and "amusement park") were generated once. The metaphors produced by participant 46 and participant 2 are as follows.

"SAC is like entertainment. Because I enjoy all my moments. "

"SAC is like an amusement park. Because I am having fun without realizing how time passes."

In the category "SAC as a developmental and guiding environment", female students produced 8 different metaphors (f: 8) and male students elicited 11 different metaphors (f: 12). The frequency of generated metaphors is 1 among the female students and 1 to 2 metaphors among the male students. "experiments", "spectacles", "light" metaphors were created once for each by female students. It is the "farmer" metaphor that was produced 2 times among the male students. Metaphors produced by Participant 43 and Participant 15 are as follows.

"SAC is like a farmer. Because it produces something. "

"SAC is like light. Because it enlightens us. "

In "SAC as a source and conveyor of information" category, female students produced 12 different metaphors (f: 12) and male students produced 5 different metaphors (f: 11). The frequency of generated metaphors is between 1 and 2 among the female students and between 1 and 6 among the male students. The most common metaphor is "book"(f:2) by female students, and "school"(f:6) by male students. The metaphors produced by Participant 40 and Participant 11 are as follows.

"SAC is like a book. Because it teaches us new things. " 
"SAC is like a school. Because it gives us information. "

In "SAC as a beneficial learning environment" category, female students produced two different metaphors (f: 2) and male students produced 3 metaphors (f: 3 ). The frequency of generated metaphors is 1 in all the metaphors by male and female students. The "factory" and "life" metaphors are by female students, and the "school", "project" and "sports" metaphors are by male students. The metaphors produced by Participant 19 and Participant 4 are as follows.

"SAC is like a factory. Because it produces a lot of projects. "

"SAC is like a sport. Because it always benefits us everywhere. "

In the category "SAC as a surprising learning environment", female students generated 3 metaphors (f: 3 ) and male students produced two metaphors (f: 2). The frequency of generated metaphors is 1 in all the metaphors by both male and female students. Female students produced the metaphors of "world", "music" and "number pi" and male students produced the metaphors of "movie" and "magic box". The metaphors produced by Participant 27 and Participant 2 are as follows.

"SAC is like the world. Because it is not clear what will come out of it. "

"SAC is like a movie. Because you do not understand how it starts and how it ends. "

Female students didn't produce any metaphors in the category "SAC as a boring learning environment". Male students produced 1 different metaphor (f:1). Male students produced "SAC as a boring learning environment" metaphor. The metaphor produced by Participant 23 is as following.

"SAC is like a boring place. Because time is not passing by and it makes me unhappy. "

3.3 Distribution of Gifted Students' Metaphors Related to the Concept of "SAC" According to the Education Programs They were enrolled

Table 12. Distribution of metaphors related to SAC concept according to education programs they were enrolled

\begin{tabular}{|c|c|c|c|c|}
\hline Conceptual Category & $\begin{array}{l}\text { Support training Program } \\
(\mathrm{N}=17)\end{array}$ & $\begin{array}{l}\text { Individual Capabilities Recognition } \\
\text { Program }(\mathrm{N}=17)\end{array}$ & $\begin{array}{l}\text { Special Capabilities Development } \\
\text { Program }(\mathrm{N}=18)\end{array}$ & $\mathrm{f}$ \\
\hline $\begin{array}{l}\text { 1. SAC as Safe and } \\
\text { Relaxing Environment }\end{array}$ & $\begin{array}{l}\text { mom (f:2), family (f:1), } \\
\text { friend (f:1), heaven (f:1) } \\
\text { Metaphor:4, f:5 }\end{array}$ & $\begin{array}{l}\text { home (f:3), family (f:2), tree (f:1), } \\
\text { mom (f:1), freedom (f:1) } \\
\text { Metaphor:5, f:8 }\end{array}$ & $\begin{array}{l}\text { canvas (f:2), friend (f:1), flower } \\
(f: 1) \text {, world (f:1), music (f:1), love } \\
\text { (f:1), family tree (f:1), song (f:1), } \\
\text { pillow (f:1), nest (f:1) } \\
\text { Metaphor:10, f:11 }\end{array}$ & 24 \\
\hline $\begin{array}{l}\text { 2. SAC as Entertaining } \\
\text { Learning Environment }\end{array}$ & $\begin{array}{l}\text { entertainment (f:1), house } \\
\text { (f:1) } \\
\text { Metaphor:2, f:2 }\end{array}$ & $\begin{array}{l}\text { life (f:1), dude (f:1), amusement park } \\
(f: 1) \text {, game (f:1), play house (f:1) } \\
\text { Metaphor: } 5, f: 5\end{array}$ & $\begin{array}{l}\text { entertainment (f:3), lesson (f:1), } \\
\text { fellow (f:1), fun fair (f:1), happiness } \\
(f: 1) \text {, music box (f:1), play house } \\
(f: 1) \\
\text { Metaphor:7, f:9 }\end{array}$ & 16 \\
\hline $\begin{array}{l}\text { 3. SAC as } \\
\text { developmental and } \\
\text { guiding environment }\end{array}$ & $\begin{array}{l}\text { farmer (f:1), experiment } \\
(f: 1) \text {, ladder (f:1), compass } \\
(f: 1) \\
\text { Metaphor:4, f:4 }\end{array}$ & $\begin{array}{l}\text { brain (f:1), farmer (f:1), climber } \\
\text { (f:1), build a house (f:1), future (f:1), } \\
\text { glasses (f:1), dairy (f:1), light (f:1), } \\
\text { teacher (f:1), field (f:1) } \\
\text { Metaphor:9, f:9 }\end{array}$ & $\begin{array}{l}\text { glint (f:1), book (f:1), candle (f:1), } \\
\text { guide (f:1), technology (f:1), } \\
\text { master (f:1), leaf (f:1) } \\
\text { Metaphor:7, f:7 }\end{array}$ & 20 \\
\hline $\begin{array}{l}\text { 4. SAC as the Source } \\
\text { and Conveyor of the } \\
\text { Information }\end{array}$ & $\begin{array}{l}\text { book (f:2), school (f:2), } \\
\text { sky (f:1), course (f:1), } \\
\text { maths (f:1), learning place } \\
\text { (f:1) } \\
\text { Metaphor: } 6, f: 8\end{array}$ & $\begin{array}{l}\text { school (f:4), garden (f:1), sun (f:1), } \\
\text { star (f:1) } \\
\text { Metaphor: 4, f:7 }\end{array}$ & $\begin{array}{l}\text { book (f:2), computer (f:1), } \\
\text { info house (f:1), notebook (f:1), } \\
\text { course (f:1), school (f:1), teacher } \\
\text { (f:1) } \\
\text { Metaphor: 7,f:8 }\end{array}$ & 23 \\
\hline $\begin{array}{l}\text { 5. SAC as Beneficial } \\
\text { Learning Environment }\end{array}$ & $\begin{array}{l}\text { factory (f:1), school (f:1), } \\
\text { project (f:1), sport (f:1) } \\
\text { Metaphor: } 4, \mathrm{f}: 4\end{array}$ & Metaphor:0, f:0 & $\begin{array}{l}\text { life (f:1) } \\
\text { Metaphor:1, f:1 }\end{array}$ & 5 \\
\hline $\begin{array}{l}\text { 6. SAC as Surprising } \\
\text { Learning Environment }\end{array}$ & $\begin{array}{l}\text { world (f:1) } \\
\text { Metaphor: } 1, \mathrm{f}: 1\end{array}$ & $\begin{array}{l}\text { film (f:1), magic box (f:1) } \\
\text { Metaphor:2, f:2 }\end{array}$ & $\begin{array}{l}\text { music (f:1), number pi (f:1) } \\
\text { Metaphor: } 2, \mathrm{f}: 2\end{array}$ & 5 \\
\hline $\begin{array}{l}\text { 7. SAC as Boring } \\
\text { Learning Environment }\end{array}$ & $\begin{array}{l}\text { Boring place (f: } 1 \text { ) } \\
\text { Metaphor: } 1, \mathrm{f}: 1\end{array}$ & Metaphor:0, f:0 & Metaphor:0, f:0 & 1 \\
\hline
\end{tabular}

Examining the table 12, students were enrolled in the support training program produced 4 different metaphors (f:5), students who were enrolled in the Individual Capabilities Recognition Program produced 5 different metaphors (f:8), and the students who were enrolled in Special Capabilities Development Program produced 10 different metaphors (f:11) in "SAC as a safe and relaxing environment" category. The frequency of the produced metaphors by the students who were enrolled in the support training program was between 1-2, by the students 
who were enrolled in the Individual Capabilities Recognition Program was between 1-3 in, and between 1-2 in the students who were enrolled in the Special Capabilities Development Program. The most frequently repeated metaphors by students who were enrolled in the support training program were; "mom" (f:2), and"home"(f:3) by students who were enrolled in the Individual Capabilities Recognition Program, and the " Canvas " (f2)by students who were enrolled in the Special Capabilities Development Program. The metaphors produced by Participant 7, Participant 6 and Participant 51 are as follows.

"SAC is like my mother. Because it always supports me. "

"SAC is like home. Because it's where I rest and relax. "

"SAC is like a canvas. Because it shows what we do. "

The students who were enrolled in the support training program produced 2 different metaphors (f: 2), students who were enrolled in the Individual Capabilities Recognition Program produced 5 different metaphors (f: 5), students who were enrolled in the Special Capabilities Development Program produced 7 different metaphors (f: 9) in "SAC as an entertaining learning environment" category. The frequency of generated metaphors is, 1 for the students who were enrolled in the support training program, 1 for the students who were enrolled in the Individual Capabilities Recognition Program, and between 1-3 for the students who were enrolled in the Special Capabilities Development Program. The "entertainment" and "home" metaphors were generated by 2 students who were in the support training program . The "life," "dude" metaphors were produced by students who were enrolled in the individual capabilities recognition program. The "entertainment" metaphor was elicited by the students who were enrolled in the Special Capabilities Development Program. Metaphors produced by Participant 3, Participant 22 and Participant 46 are as follows.

"SAC is like entertainment. Because we are having fun with the experiments we do. "

Because it makes me very happy. "

"SAC is like entertainment. Because it's enjoyable to spend time there. "

Students who were enrolled in the support training program produced 4 different metaphors (f:4), students who were enrolled in the individual capabilities recognition program produced 9 different metaphors (f:9), students who were enrolled in the Special Capabilities Development Program produced 7 different metaphors (f:7) for the "SAC as a developmental and guiding environment" category. The frequency of generated metaphors is, 1 for the students who were enrolled in the support training program, 1 for the students who were enrolled in the individual capabilities recognition program, and 1 for the students who were enrolled in the Special Capabilities Development Program. The "farmer", "experiment", and "ladder" metaphors were formed by the students who were enrolled in the support training program, the "brain," " dairy ", and "glasses" metaphors were generated by students who were enrolled in the individual capabilities recognition program, and the "glint", "book", and "candle" "entertainment" metaphors were formed by the students who were enrolled in the the Special Capabilities Development Program. The metaphors produced by Participant 29, Participant 2 and Participant 50 are as follows.

"SAC is like a ladder. Because you move forward as you pass the chapters. "

"SAC is like a dairy. Because it helps us to improve our memory. "

"SAC is like a master. Because it sharpens our talents. "

Students who were enrolled in the support training program produced 6 different metaphors (f:8), students who were enrolled in the individual capabilities recognition program produced 4 different metaphors (f:7), students who were enrolled in the the Special Capabilities Development Program produced 7 different metaphors (f:8) in the SAC as the Source and Conveyor of the Information category. The frequency of generated metaphors is, between 1-2 by the students who were enrolled in the support training program, between 1-4 by the students who were enrolled in the individual capabilities recognition program, and between 1-2 by the students who were enrolled in the the Special Capabilities Development Program. The "book", and "school" metaphors were produced by two students who were enrolled in the support training program, the "school," metaphor was formed by four students who were enrolled in the individual capabilities recognition program, and the "book" metaphor was formed by two students who were enrolled in the the Special Capabilities Development Program. The metaphors produced by Participant 40, Participant11 and Participant 48 are as follows.

"SAC is like a book. Because he's teaching us new things. "

"SAC is like a school. Because it gives us new information. " 
"SAC is like a book. Because it contains a lot of information. "

Students who were enrolled in the support training program produced 4 metaphors (f:4), but the students who were enrolled in the individual capabilities recognition program didn't produce any metaphors in "SAC as the Beneficial Learning Environment category". Students who were enrolled in the the Special Capabilities Development Program produced 1 metaphor (f:1). The frequency of generated metaphors is 1 for the students who were enrolled in the support training program, 1 for the students who were enrolled in the the Special Capabilities Development Program. The "factory", "school" etc metaphors were formed by the students who were enrolled in the support training program, and the "life" metaphor was formed by one student who was enrolled in the Special Capabilities Development Program. The metaphors produced by Participant 4, and Participant 10 are as follows.

"SAC is like a project. Because it is useful to us. "

"SAC is like life. Because it is the life itself. "

Students who were enrolled in the support training program produced 1 metaphor (f:1), students who were enrolled in the individual capabilities recognition program produced 2 metaphors (f:2), students who were enrolled in the Special Capabilities Development Program produced 2 metaphors (f:2) in thecategory "SAC as a surprising learning environment" The frequency of generated metaphors is 1 by the students who were enrolled in the support training program, between 1-2 by the students who were enrolled in the individual capabilities recognition program, and between 1-2 by the students who were enrolled in the Special Capabilities Development Program. The "world " metaphor was formed by one student who was enrolled in the support training program, the "film," and "magic box" metaphors have been formed by two students who were enrolled in the individual capabilities recognition program, and the "music," and "number pi" metaphors were formed by the students who were enrolled in the Special Capabilities Development Program. The metaphors produced by Participant 27, Participant 2, and Participant 37 are as follows.

"SAC is like the world. Because it is not clear what will come out of it. "

"SAC is like a movie. Because you do not know how it starts and how it ends. "

"SAC is like number pi. Because you will be surprised when you get inside. "

Students who were enrolled in the support training program produced 1 metaphor (f:1), students who were enrolled in the individual capabilities recognition and the Special Capabilities Development Program didn't produce any metaphors in the SAC as the Boring Learning Environment category. The frequency of generated metaphors is, 1 for the students who were enrolled in the support training program, and no frequency has been generated in other categories. The "boring place " metaphor has been formed by the students who were enrolled in the support training program. The metaphor produced by Participant 23 is as following.

"SAC is like a boring place. Because time is not passing by and it makes me unhappy. "

\section{Discussion}

Given the metaphors of gifted students regarding the SAC concept, it can be said that the gifted students' perceptions of the SAC concept are positive. The "school", "book", "entertainment", "home", "family", "mom" metaphors produced by the gifted students are the most produced metaphors. When the metaphors of the SAC concept of the gifted students are discussed from the point of common features, gifted students seeSACs as a safe and relaxing environment, as a source and conveyor of information, as adevelopmental and guiding environment, as an entertaining learning environment, as a beneficial learning environment, as a surprising learning environment, and as a boring learning environment. When the themes of the SAC concept were examined, it was seen that 5 out of 7 themes had positive opinions, 1 of them contained surprising learning environment metaphors and only 1 of them was seen as a boring learning environment. When the ratio is checked it is seen that SAC is metaphorically associated with highly positive content. Examining the generated codes of the themes, gifted students produced metaphors that emphasized they were responsible. Metaphor frequencies show that their social and emotional developments are higher than their peers. They also produced metaphors that could solve problems and provide interdisciplinary relationships in specific situations they encountered. These metaphors produced by gifted students related to SAC concept, the "SAC as Developmental and Guiding Environment" theme created by the researcher overlaps with the item "recognize national and universal values, adopt, develop and respect these values, and develop their leadership, creative and productive thinking skills in a national and social way to contribute to the development of the country..." in the objectives part item 6.1.b of the SAC Directive published by the Ministry of National Education (2015). SAC as a Safe and Relaxing Environment and the Source and Conveyor of Information themes created by the researcher overlap 
with the item 6.1.c. "the areas of social and emotional development to be dealt in unity in the process development of ability area/s".

SAC as a Beneficial Learning Environment theme created by the researcher overlaps with the items 6.1.c. and 6.1.d. "Being aware of and trying develop their talents and creativity at an early age, being aware of their own talents and using it by developing their own capacities at the highest level". SAC as a Surprising Learning Environment theme created by the researcher overlaps with the item 6.1.g. "Gaining the discipline of scientific work in the direction of their own special talents, interdisciplinary thinking, solving the problems or realizing the projects to meet the determined needs ...". Metaphors produced by gifted students related to SAC concept and themes made by the researcher are also supported by other researches (Cerit, 2006, Demir, 2005, Kunt and Tortop, 2013). The perception of the concept of the school is very important for the students who receive non-formal education while they continue their formal education. There are also positive (Demir, 2005; Cerit, 2008; Peterson \& Lorimer, 2012; Kunt ve Tortop, 2013), or negative (Gallagher vd., 1997; Saban, 2011) views of the new school that the students meet. Looking at the research, it is seen that the perceptions of gifted students are very positive. This suggests that SAC is an institution that serves its purpose.

According to the findings of the research, SAC as a Safe and Relaxing Environment theme has the most frequency among 7 different themes. This means that gifted students consider SACs as a safe and relaxing environment. When frequency values considered this theme is followed by SAC as the source and conveyor of information. Moreover, gifted students consider SACs as an information source and the place where it is transmitted. This shows that in the logical framework, SAC institutions are on the right path to serve for their general purposes. It is also seen that SAC as a Boring Learning Place themehas the lowest frequency value.

When the metaphors that gifted students have produced $i$ about the concept of SAC are considered in terms of gender variable they are found sub-objective; there are differences among the frequencies of 4 out of 7 themes In three themes, frequencies are close to each other. It has been noted by the researcher that female students are more involved than male students. Female students regard SACs as more reliable, more relaxing, more entertaining, source and conveyor of information compared to male students. Male students regard SACs as a developmental, guiding environment compared to female students. Other themes are close to each other. Researches (Sadık ve Sarı, 2012; Kunt ve Tortop, 2013) conducted in this direction also supports the obtained data.

When the metaphors that gifted students produced about the concept of SAC are considered in terms of the enrolled educational programs they are found sub-objective; there are differences among the frequencies of 5 out of 7 different themes. In two themes, frequencies were close to each other. The researcher stated that the number of students involved in the research from different training programs was almost equal. Students who enrolled in the Special Capabilities Development Program view SAC as safer, more relaxing, more entertaining, source and conveyor of information compared to students enrolled in the other education programs. Students who attend the individual capabilities recognition program view SAC as more developmental and guiding than students who attend other education programs. Students who attend the Support training program view SAC as a beneficial learning environment compared to the students who attend other educational programs. Although there have been similar studies in this respect (Kunt and Tortop, 2013), no study has been found in literature focusing the program variable of the gifted students. Tortop (2013) suggested that metaphorical perceptions could be an assessment tool for the evaluation of training programs. In this context, it is possible to have an idea about the social validity of the program by taking the students' metaphorical perceptions about the program and their opinions about the program of Science and Art Centers where the gifted students are educated.

It is recommended that practitioners prepare individual training programs to be used in the lessons by taking into account the positive and negative metaphors created by gifted students, and SACs' learning environments can be designed according to the characteristics of gifted students. Studies may suggest that teachers working at SAC study on metaphoric perceptions for educational programs.

\section{Acknowledgement}

This study was produced first author' master thesis.

\section{References}

Akkanat, H. (2004). Üstün veya Özel Yetenekliler, Türkiye Üstün Yetenekli Çocuklar Kongresi. Seçilmiş Makaleler Kitabı, İstanbul: Çocuk Vakfı Yayınları.

Arnett, R. C. (1999). Metaphorical Guidance: Administration As Building And Renovation. Journal of Educational Administration, 37(1), 80-89. https://doi.org/10.1108/09578239910253953 
Baş, T., \& Akturan, U. (2008). Nitel araştırma yöntemleri: Nvivo7.0 ile nitel veri analizi. Ankara: Seçkin Yayıncilik.

Cerit, Y. (2008). Öğretmen Kavramı İle İlgili Metaforlara İlişkin Öğrenci, Öğretmen ve Yöneticilerin Görüşleri. Türk Ĕ̈itim Bilimleri Dergisi, 6(4), 693-712.

Ehly, S. W., Conoley, J. C., \& Rosenthal, D. (1985). Working with Parents of Exceptional Children, Mosby College Publishing, Toronto Santa Clara.

Evin, G. İ., \& Satmaz, İ. (2016). Attitudes of prospective teachers towards education of gifted students. 4th International Conference on Curriculum and Instruction, ANTALYA, TÜRKIYE, 27-30 Ekim, pp.473-474.

Gallagher, J., Harradine, C. C., \& Coleman, M. R. (1997). Challenge or boredom? Gifted students' views on their schooling. Roeper Review, 19(3), 132-136. https://doi.org/10.1080/02783199709553808

Kaya, N. G. (2013). Üstün Yetenekli Öğrencilerin Eğitimi ve BİLSEM’ler. Erzincan Üniversitesi Eğitim Fakïltesi Dergisi, 15(1), 115-122.

Kunt, K., \& Tortop, H. S. (2013). Türkiye'deki üstün yetenekli öğrencilerin bilim ve sanat merkezlerine ilişkin metaforik algıları. Üstün Yetenekliler Eğitimi Araştırmaları Dergisi, 1(2), 117-127.

Küçükyılmaz, A., \& Duban, N. (2006). Sınıf öğretmeni adaylarının fen öğretimi öz yeterlilik inançlarının artırılabilmesi için alınacak önlemlere ilişkin görüşleri, [The opinions of primary teacher candidates on taking measures to increase science teaching self-efficacy beliefs]. Yüzüncü Yll Üniversitesi Eğitim Fakültesi Dergisi, 2, 1-23.

MNE SAC Directive MEB (Milli Eğitim Bakanlı̆̆ı), (2015). Bilim ve Sanat Merkezleri Yönergesi, Ankara.

Meyen, E. L., \& Skrtic, T. M. (1988). Exceptional children and youth, an introduction. Denver, Colorado USA: Love Publishing Company.

Miles, M. B., \& Huberman, A. M. (1994). Qualitative data analysis. Thousand Oaks, CA: Sage.

Özer, K. M., Keskin, S. N., \& Solmaz, A. (2013). Bilim ve sanat merkezleri: Mevcut durumları, sorunları ve çözüm önerileri. Journal of Gifted Education Researches - Üstün Yetenekliler Eğitimi Araştırmaları Dergisi 1(2), Special Issue, Özel Sayı, 78-96.

Peterson, J. S., \& Lorimer, M. R. (2012). Small-group affective curriculum for gifted students: A longitudinal study of teacher-facilitators. Roeper Review, 34(3), 158-169. https://doi.org/10.1080/02783193.2012.686423

Saban, A. (2009). Öğretmen Adaylarının Öğrenci Kavramına İlişkin Sahip Olduğu Zihinsel İmgeler [Primary School Teachers' and Their Students' Mental Images about the Concept of Knowledge]. Türk Eğitim Bilimleri Dergisi, 7(2), 281-326.

Saban, A. (2011). Bilgisayar Öğretmeni Adaylarının “Okul” Ve "Bilgisayar Öğretmeni” Kavramlarına İlişkin Zihinsel İmgeleri. [Prospective Computer Teachers' Mental Images about the Concepts of "School" and "Computer Teacher]. Kuram ve Uygulamada Eğitim Bilimleri, 11(1), 423-446.

Sadık, F., \& Sarı, M. (2012). Çocuk ve demokrasi: ilköğretim öğrencilerinin demokrasi algılarının metaforlar aracıllğıly incelenmesi [Child and democracy: Examination of elementary education school students' democracy perception by metaphors]. Cumhuriyet International Journal of Education, 1(1), 48-62.

Satmaz, İ., \& Gencel, E. İ. (2016). Yeni Açılan BİLSEM’lerde Görev Yapan Öğretmenlerin Hizmet İçi Eğitim Sorunu, Buca Ĕgitim Fakültesi Dergisi, 42, 59-73.

Tortop, H. S. (2015). Üstün zekalılar eğitiminde farklılaştırılmış öğretim farklılaştırma modelleri müfredat. [Differentiated instruction in gifted education and curriculum differantiation models]. Düzce: Genç Bilge Yayıncilik.

Tortop, H. S. (2013). Öğretmen Adaylarının Üniversite Hocası Hakkındaki Metaforları ve Bir Değerlendirme Aracı Olarak Metafor. [Preservice Teachers' Metaphors about University Teacher and Metaphor as an Evaluation Tool]. Yüksekögrretim ve Bilim Dergisi, 3(2), 153-160

Türk Dil Kurumu [Turkish Language Association], (2016). Türkçe sözlük. Ankara: TDK Yayınları.

Yıldırım, A., \& Şimşek, H. (2012). Sosyal bilimlerde nitel araştırma yöntemleri. Ankara: Seçkin Yayıncılık. 


\section{Copyrights}

Copyright for this article is retained by the author(s), with first publication rights granted to the journal.

This is an open-access article distributed under the terms and conditions of the Creative Commons Attribution license (http://creativecommons.org/licenses/by/4.0/). 